\title{
DIALOGICAL PROCESSES EXAMINED: A VICTIM OFFENDER DIALOGUE CASE STUDY
}

\section{Barbara Walshe \&Janine Geske}

\begin{abstract}
This article outlines the evolution and development of Victim Offender Dialogue now seen as a growing part of the Restorative Justice movement worldwide. A case study outlines the rationale given by both victims and offender for participation and the necessary preparation undertaken to conduct an authentic process with both. An examination is made of the nature and extent of the issues explored during the dialogue and the process and outcome of the dialogue itself. This review describes moments of heartbreak, sadness and humour as the dialogue unfolds, capturing key transformational moments in the process. In conclusion, the question of forgiveness is considered, whether it was given or received.
\end{abstract}

\section{Keywords}

Dialogical process, victim, victim offender dialogue, case study

\section{Introduction}

The Restorative Justice movement has evolved through different cultures and disparate practices to challenge the current criminal justice system to think differently about addressing harm and crime.

Restorative Justice and the criminal justice system ask different questions. The criminal justice system asks; what law was broken, who broke it? How do we punish them? Restorative Justice asks: What harm was done and to whom? What needs have arisen based on that harm? Whose obligations is it to meet those needs? Howard Zehr, known as the father of Restorative Justice sees it as,

"... a process to involve to the extent possible, those who have a stake in a specific offense and to collectively identify and address harms, needs and obligations, in order to heal and put things as right as possible". (Zehr, 2002:37)

A restorative approach respects the right of the victim to challenge the harm caused by the offender and holds the offender accountable in a facilitated, safe environment. The three most common restorative practices used are Victim Offender Mediation, Family Group Conferencing and Peace-making Circles. This article will consider a process called Victim Offender Dialogue. 


\section{Victim Offender Dialogue}

In Umbreit's view (2010:212), Victim Offender Dialogue (VOD) is an outgrowth of Victim Offender Mediation (VOM) and although both are often used interchangeably, it is acknowledged that the current evolution of victim offender dialogue owes much to the mediation process. Similarities between them both include harm as an organising principle, the need for preparation, safety and reparation either real or symbolic, voluntary participation and the need for non-directive facilitation. VOD is used in the most severe crimes of violence, is more often victim initiated and only takes place after the offender has taken responsibility for the crime committed. The degree of preparation required for both victim and offender in advance of the encounter is regarded as key to its success. An assessment of the offender's readiness to participate, his/her remorse, sincerity and authenticity as well as the victim's psychological readiness are considered crucial.

The opportunity to engage in restorative processes following serious crime is offered to only $2 \%$ of cases in countries such as the UK (including Northern Ireland), Canada, the USA, New Zealand and Australia (Sherman \& Strang, 2007). These cases are carefully and meticulously prepared and facilitated in parallel to and often after lengthy prison sentences. Here the emphasis is not on diversion from a prison sentence, but on affording both the person harmed by crimes and the individual who has been responsible for them, a real and effective process of communication. This affords the person responsible for the crime the chance to acknowledge the harm done and gives the victim an opportunity to describe the impact of the crime and to receive answers to questions that often only the offender can answer. In addition to explicitly stated goals, Gustafson (2005) suggests that victims and offenders are often haunted by deeper and often unexpressed questions that guide their desires. Umbreit (2010) outlines benefits for victims as having been heard, a sense of being free from the crime of the offender and seeing the offender as a person and not a monster. He also reports that they feel less fear, more trust and greater courage. For offenders, the benefits include discovering emotions, increased awareness of the impacts of their crime, feeling good about having tried the process, achieving peace of mind and knowing they had helped a former victim (Umbreit, 2010: 215). The question of forgiveness in Restorative Justice raises much debate; suffice be it to say that while the process raises the possibility of forgiveness for both victim and offender this cannot be either prescribed or forced. (Armour \& Umbreit, 2005, 2006:232)

\section{The Case History}

An 18-year-old woman called Maria, the second eldest of a family of six children, was a front seat passenger in a friend's car when she was killed by a young man who was driving while intoxicated in 1998. There were three girls in the car at the time with a designated driver. It was reported that the young man hit the vehicle head-on while the girls were stopped at a traffic light. The offender was sentenced to four years in prison. He was subsequently released but remained under community supervision. 


\section{Background to the request for Victim Offender Dialogue (VOD)}

In early 2012 the victim's father contacted Victim Services and said that he wished to meet the offender. Mr Jones, Maria's father knew that the offender's period of community supervision was ending. He said he wanted 'closure for himself and his family', an apology from the offender and a chance to tell him that they had forgiven him. Victim services contacted the Restorative Justice Initiative based at Marquette Law School under the direction of Professor Janine Geske.

\section{Preparation for VOD}

A letter from the Restorative Justice Initiative to Mr Jones clearly outlined that time and patience would be needed to evaluate all aspects of the case to ensure a productive experience. A few months later, the RJ team met with the Jones family to assess the impact of their daughter's death. Mr Jones disclosed that he was a recovering alcoholic and that her death had caused a relapse. He felt as if the offender 'was making all the rules' and that his family had 'no say in anything'. He also disclosed certain sympathy for the offender as a recovering alcoholic himself. Mrs Jones described the pain of several significant events in her family's life which included the death of her son who had a disability four years earlier, the death of her daughter, experiencing her husband's relapse into alcoholism and facing the death of her parents. When asked what they were seeking from the VOD, Mr Jones said that he wished to know what 'the offender's life' was like now, that he 'wanted closure', a wish echoed by their two younger sons at the meeting. Patrice, Maria's youngest sister indicated that she was 'worried and nervous' about the impact of such a meeting on her. Separate sessions were offered to individual family members but they wished to go forward together. They disclosed that the offender had lived near them at one time. They also knew that his grandparents had been killed by an intoxicated driver and wondered how his own family had reacted to his offence. The younger sister wanted to know whether the offender thought about the accident. She wanted to know whether he had driven before the accident while drunk but had never been caught. The team suggested that they keep a list of questions for future meetings.

Contact with the offender John was made initially though the Probation and Parole Officer. Since he had ended his period of community supervision, a letter written by the Restorative Justice Initiative team informed him of the family's desire to meet him. They reassured him that the process was voluntary and that meetings only took place after much preparation. The letter stressed that the purpose of the meeting was to neither demonise him or to re-victimise the Jones family but rather to act as a healing process for everyone. It outlined his need to take complete responsibility for what happened. The offender John indicated significant interest. Telephone contact was set up with one of the team. During those calls he expressed his fear of the family's anger that 'he had done a horrible thing' and wanted, if that was possible, to contribute to closure for the family. A face to face meeting was arranged with him. He told them that he had obtained a Master's degree in pastoral counselling; however, he hadn't been able to find a job in the field because of his felony conviction and now worked as a manager in a restaurant. He also indicated that he hadn't touched 'a drop of alcohol since the incident'. While fearful of meeting the family he felt it was the least he could do in the circumstances'. He said that he found it hard to live with 'a family that hates me because I killed 
their danghter, it's not who I am'. He also indicated that he wanted to make public amends to them by funding a scholarship in Maria's name. The team wrote to the Jones family with a short summary of what John had said and encouraged them to write down any questions they might have for him. Contact was maintained by members of the RJ team during the following months.

\section{Before the Encounter}

The dialogue was held in a meeting room at Marquette University Law School. The facilitator welcomed the family and brought $\mathrm{Mr}$ and Mrs Jones and their two daughters, Susan and Patrice, into the room. Their two younger sons had decided not to participate. Four chairs had been arranged on one side of the table and one chair for the offender John was positioned opposite the family. The facilitator was positioned between both parties. Water, tissues and candy had been placed on the table. The Jones family sat down at the table, continuously being reassured by the facilitator.

Before John came into the room, the facilitator told the family that she had met and prepared John for this meeting. She explained that he was very nervous and that it was not easy to face the people that he had hurt. She outlinedagain that she was there to make them all as comfortable as possible.

The facilitator welcomed John. The atmosphere was tense as the facilitator worked to put everybody at ease. She smiled encouragingly and reassured them that the goal of the entire process was to encourage healing and give them a chance to talk to each other. She also told them that she wouldn't be saying a great deal during the process except to ensure that everyone got an opportunity to say what was in their hearts and to clarify issues if needed.

\section{The Dialogue}

Mr Jones asked John what he had remembered from the night his daughter was killed, and how he had felt about it since.

John told them that he had been drinking in a bar and when he was leaving, one of his friends had questioned whether he was fit to drive. Assuring them that he was, he travelled a short distance and crashed into a car killing one of the occupants. When he saw the car and the extent of their injuries, he said he knew that night that his life had changed forever. Since then, he had a sense of 'life before' and 'life after' the fatality. The facilitator encouraged him to talk more about his life. He explained that both his grandparents had been killed in a road traffic accident when he was in his freshman year in college and he remembered having to tell his parents. Maria's father's cries at the hospital brought back the memories of the death of his grandparents. He said that after their deaths, he started drinking more frequently. He also told the family that he hadn't touched any drink since the accident.

\section{Maria's mother speaks}

Maria's mother went on to talk about the birth of her first son who had a disability due to a birth injury. He had died at sixteen from pneumonia and complications. She described their joy and relief when Maria was born perfect, was full of life and subsequently lived life to the full. Her death, she said, shattered all of 
their family. She also related that she blamed herself. She said that she hadn't given the offender John much thought initially because of her entire family's trauma. She remembered seeing John handcuffed to the chair in the hospital and remarked on how different he looked when she saw him in Court. She told John that she was now a victim advocate and gave public talks to raise awareness about the hazards of drinking and driving. She shared that her now oldest daughter was getting married in three weeks and it would be both a sad and happy time for them. Her children were her whole world and that, like any mother, losing her children was very hard. A woman of strong faith, she felt certain that she would be reunited with her deceased children after her death.

The video was then shown, picturing Maria's life as a tiny baby, her first Holy Communion picture, Christmas photographs, her graduation from college with her friends and family. A photograph of the crashed vehicle appeared on the screen, John cried as he watched it. Susan, one of the sisters pushed the tissue box across the table to him.

\section{Maria's sister Susan speaks}

Maria's sister Susan talked about her loss as both had gone to the same high school. She talked about the impact of her sister's death, the pressure of now being the eldest in the family, of being a role model for her sister and brothers, and her upcoming wedding. She talked about the importance of having a trustworthy partner who didn't drink alcohol. She also spoke about Maria's last visit home, how she had talked to everyone in the family, how she visited all the rooms in the house before leaving and how she had uncharacteristically done all her shopping for Christmas presents and had insisted that they be placed under the tree for everyone.

\section{Ongoing Dialogue}

The facilitator encouraged John to tell his story more deeply but he said that he was afraid that by doing that, it appeared to minimise their suffering. Patrice asked him about the prisons he had been in and he talked about that, the support he received from his family, and particularly his mother who wrote to him every day. He felt that prison was an easier option for him, compared to their loss. He prayed for the family every night.

Susan asked him about his life now. He said that he had been married for five years, had a dog and was manager at a restaurant. Patrice also asked him about how soon he told his wife about being in prison. He answered that he had told her about a month after they started going out. He talked about having an addictive personality type. In prison, he used the gym all the time. He now over eats and when he drank, he drank too much.

Patrice, Maria's younger sister had been quiet throughout the meeting, often crying quietly. She explained that that she couldn't remember her sister very well now and this distressed her. She talked about her sadness when the younger children in the family asked about Maria, because they never knew her.

Slowly, members of the family started to talk about the offender's sincerity and his 'genuineness'. They said that they could see that he felt very sorry and had never meant this to happen. Mr Jones then talked 
about his own drinking and said that in different circumstances, it could have been him who was driving a car while intoxicated. The facilitator encouraged John to talk about his idea of setting up a scholarship in Maria's name in her College. The family seemed surprised but nodded to each other and seemed to think it was a good idea. The facilitator suggested a break. John left the room to give the family some space to think things over.

The meeting reconvened. The scholarship was discussed and agreement for contact between both parties was agreed. A moment of humour and levity entered as Mr Jones told John that 'he loved to eat' and asked whether he was going to give them any coupons for the restaurant. John looked at them uncertainly to see if they were serious and agreed to do so.

Mr Jones suggested that John might work with him and his wife on Victim Impact Panels and also suggested that AA would give him support with his drinking as it did with his. This was readily agreed to.

At the end of the meeting which lasted under two hours, the victim's mother embraced John as did both sisters and the father shook his hand. Then John cried and cried. So also did members of the family.

\section{Comment}

The dialogue lasted just over two hours and could be regarded as being a very satisfactory encounter. The entire process took eighteen months to prepare and occurred fifteen years after the victim's death. This encounter could not have happened without the referral from the Wisconsin Department of Corrections Victim Services, which facilitates requests from victims to meet their offender as part of their work. It is also significant that a Restorative Justice Initiative existed which had facilitators to prepare and manage he dialogue in a professional, safe and compassionate manner.

As previously stated, a thorough preparation process enabled the Jones family and John to safely engage with the questions they had for each other. Because of the individual meetings, and passing of information between both parties, the family knew that he was remorseful and accepted responsibility. John was told that Maria's family were not angry but sad and had questions for him about what had happened. The family were trying to take some meaning out of the tragic loss of their daughter. They had a sense that Maria was saying goodbye to them all before the accident and that it was 'meant to be'. It was evident that the mother's strong faith reassured her that she would meet her children in an afterlife.

The role of the facilitator was key to the development of the Victim Offender Dialogue, creating a safe, neutral space with firm boundaries for both, creating the conditions for storytelling and interrupting only to encourage John to deepen his story. This facilitated process gave the Jones family a greater sense of the man John was. His remorse and sorrow was evident from the beginning, in that he listened more than he talked, he minimised his own suffering, his time in prison, his inability to get a job in pastoral counselling, having to take instead a job in a restaurant. He cried with the family as they watched Maria's video and his wish to make amends in a public way through funding a scholarship in her name, doing some victim impact work and his stated desire not to be defined by 'the worst thing that he had done in his life' was powerful.

John's sorrow and remorse influenced the dynamic in the dialogue for the family as empathy developed between them both. Transformational moments occurred when Maria's father's stated that 'it (causing a 
fatal accident) could have been him' because of his struggle with alcoholism and also when the family's acknowledged John's 'genuineness'. While the word forgiveness was not mentioned, the energy in the room was one of forgiveness as Mrs Jones and her two daughters embraced John and Mr Jones shook his hand.

When Mr Jones was contacted a number of weeks after the dialogue, he described the process as 'amazing'. John saw the offer of the tissue box from Patrice as he watched the video of Maria's life as an olive branch for which he expressed profound gratitude. 


\section{References}

Armour, M. \& Umbreit, MS. (2005) The paradox of forgiveness in restorative justice. In E.L. Worthington, Jr. (Ed.)

Handbook of Forgiveness (pp.491-505). New York: Brunner-Routledge.

Armour, M. \& Umbreit, MS. (2006) Victim forgiveness in restorative justice dialogue. Victim and Offender, $1(2), 123-140$.

Gustafson, D (2005) Exploring treatment and trauma recovery, implications of facilitating victim offender encounters in crimes of severe violence: Lessons from the Canadian experience. In E. Elliot and R.M. Gordon (Eds.) New directions in Restorative Justice: Issues, Practice and Evaluation(pp.193-227)

Sherman, Lawrence W and Strang, Heather (2007) Restorative Justice: the Evidence: London, the Smith Institute: http://www.restorativejustice.org/10fulltext/restorative-justice-the-evidence

The Office of Crime Victim Services (OCVS). The Wisconsin Department of Justice

http://www.doj.state.wi.us/ocvs/office-crime-victim-services

Umbreit, M. PhD. Peterson Armour, M., PhD. Restorative Justice Dialogue: An Essential Guide for Research and

Practice. ISBN: 987-0-8261-2258-2, Springer Publishing Company LLC, 11 West $42^{\text {nd }}$ Street, New York, NY 10036.

Zehr, H. (2002). The little book of Restorative Justice. Intercourse, PA: Good Books. (p. 37)

\section{The Authors}

Justice Janine P. Geske currently serves as a Distinguished Professor of Law at Marquette University Law School and Director of the Law School's Restorative Justice Initiative. She is a retired Wisconsin Supreme Court Justice and trial court judge. She has been actively involved in restorative justice work for over twelve years and now travels and trains extensively internationally in the area of Restorative Justice.

Barbara Walshe is a researcher, teacher, story teller and restorative justice facilitator. She is a member of Facing Forward, a non-governmental organisation working to make restorative justice a part of the mainstream criminal justice system in Ireland. 